\title{
Portrayal of Adolescents with Autism Spectrum Disorder in Young Adult Literature
}

\author{
Rhonda S. Black \\ Courtney A. Tsumoto \\ University of Hawaii at Manoa
}

\begin{abstract}
Characters with autism spectrum disorders (ASD) have become increasingly popular in young adult literature. Using a case-study format, this article describes the communication, sensory, and social characteristics of eight protagonists in award-winning young adult novels. All told in the first person, these novels provide insight for young readers regarding what youth with ASD experience. General findings reveal that youth with ASD are portrayed as quirky geniuses, who are sensitive to sounds and light, and are thrown off by changes in routine or in the environment. Misunderstanding idioms is used as comic relief, as are the characters' social faux pas. The characters do not represent the full range of individuals with ASD, especially those who also have cognitive and language impairments. The novels do portray sensory sensitivity well from a first-person perspective. Overall, the novels provide positive images that may challenge ableist attitudes and promote peer acceptance.
\end{abstract}

During the last two decades, the number of children in the United States diagnosed with autism spectrum disorder (ASD) has dramatically increased to 1 in 68 children (Centers for Disease Control, 2015, 2016), up from 1 in 150 children in 2000 (Centers for Disease Control, 2011). There has been a parallel increase in the number of studies in medicine, psychology, and education focusing on children with ASD (Jang et al., 2014). Simultaneously with the increase in ASD incidence, news reports, parenting guides, autobiographies, documentaries, movies, and literature are shining a spotlight on the many faces of ASD. 
For the general population, much of their learning about ASD comes from the popular press or visual media. For example, the 1988 film Rain Man has served as a cultural reference point for ASD for over 25 years. According to Murray (2010), Rain Man is the breakthrough cultural text that brought ASD to a wide public audience and is still the seminal cultural text depicting the condition. When explaining ASD to someone who has not had personal experience with some of the characteristics such as lack of eye contact or repetitive behaviour, a reference such as, "You know, he's like Rain Man," is not uncommon.

The number of characters with ASD in adolescent literature has also increased in recent years (Irwin, Goldsmith, \& Applegate, 2015). Perhaps the increase can be attributed to growing public curiosity about, and awareness of ASD. It may also be due to more students with ASD participating in general education classes with their peers. These young adult novels depict characters with diverse experiences largely reflecting research on actual teens (Irwin et al., 2015). Mark Haddon's The Curious Incident of the Dog in the Night-Time (subsequently referred to as Curious Incident), is perhaps the most popular of these novels. It became a worldwide best-seller in 2003, and has since sold over 10 million copies, has been translated into 44 languages, and has won 17 literary awards (Clinton, 2014). Perhaps more importantly, Curious Incident has been adopted by many secondary schools as recommended reading and is therefore becoming a cultural reference point for young people regarding ASD. "Although this is just one fictional representation of a teen with ASD, the portrayal of Christopher received so much attention that readers without previous knowledge of autism might consider it normative of all individuals on the spectrum" (Irwin et al., 2015, p. 4). Curious Incident has brought international attention to a single teen character with ASD and started a rising wave of novels written from the perspective of a young person with ASD (Robinson, 2012). As more adolescents read these novels, it is important to analyze and assess how individuals with ASD are being portrayed and what messages are being sent.

\section{Purpose}

Young adult literature (YAL) has the power to bring to light common experiences, emotions, and dilemmas while also promoting respect for differences. However, stereotypical representations can lead to erroneous perceptions. Analyzing the stories told by YAL protagonists may provide insight into messages sent to young people about their peers who experience ASD. Starting with Curious Incident as a reference point, this review of ten YAL books asks: What characteristics are portrayed in teen protagonists with ASD? More specifically, how are characters with ASD portrayed with respect to understanding language, the need for structure, sensory sensitivity, and social characteristics?

\section{Method}

To answer the questions above, a descriptive case-study method was selected (Yin, 2009). According to Yin (2009), case studies are a preferred method in situations where relevant behaviours cannot be manipulated and serve a purpose of illustrating certain topics in a descriptive mode. Case-study descriptions may be literary in nature to convey the researcher's understanding of the case (Merriam, 2009). Our data consisted of the 
YAL authors' narrative descriptions of the protagonists with ASD. In this review, each novel and its protagonist was analyzed as an individual case. Characteristics of the casestudy subjects were described in a narrative format (Silverman, 2004) followed by a cross-case analysis of similarities and differences between cases and characters in the selected novels.

\section{Selection Criteria}

Novels selected for review met five criteria:

1. The novel was written in English and had the designation of YAL. As defined, YAL is a fictionalized piece written, published, and marketed to adolescents and young adults. The American Library Association (ALA) defines a young adult as someone between the ages of 12 and 18 years.

2. The novel was written after the year 2000 and depicted current circumstances for a teen with ASD. We excluded historical novels focusing on the past, and science fiction projecting into the future.

3. The novel was an award winner in the YAL category. Recommended reading lists for teachers and students are compiled from awards lists, and are the most probable books introduced to young adult readers.

4. The novel's main character with ASD is a young adult. We included characters ranging from ages 11 to 19 years.

5. The novel is told from the perspective of a protagonist with ASD. We excluded books told from another's perspective primarily because those books focused on a neurotypical protagonist's experience of being with someone with ASD, not directly experiencing ASD.

The selection process began by reviewing award lists published by divisions of the ALA. These lists included the Young Adult Library Services Association's (YALSA, one such division) list of Best Books for Young Adults from 2000 to 2017; followed by Schneider Family Book Award recipients in the teen category. The Schneider Family Book Award is given annually to recognize authors and illustrators for their distinguished portrayal of people living with a disabling condition. We also reviewed winners of the biennial Dolly Gray Children's Literature Award sponsored by the Division on Autism and Developmental Disabilities of the Council for Exceptional Children. To further the search, we then reviewed sources of information listing books in this category (American Library Association, 2009; Dyches, Prater, \& Leininger, 2009; Prater \& Dyches, 2008; Rosenblum \& Carroll, 2000; Ward, 2002), along with Wikipedia's (2017) list of fictional characters on the autism spectrum. Ten books (with eight characters) met the selection criteria (see Appendix).

\section{Analysis}

The protagonist of each selected novel was considered a case. We analyzed the way these protagonists were portrayed using diagnostic hallmarks identified by the American 
Psychiatric Association's (2013) Diagnostic and Statistical Manual (DSM-5) diagnostic criteria for an autism spectrum disorder (see also Centers for Disease Control and Prevention, n.d.). We started by describing each protagonist or case in detail (Gillham, 2010). We then coded our data according to the following diagnostic criteria:

- Persistent difficulties in the social use of verbal and non-verbal communication.

- Difficulty in developing, maintaining, and understand relationships.

- Restricted, repetitive patterns of behaviour or activities. Fixated interests that are abnormal in intensity or focus.

- Insistence on sameness, inflexible adherence to routines.

- Hyper- or hypo-reactivity to sensory input or unusual interest in sensory aspects of the environment.

To summarize our findings, we created brief vignettes of the protagonists' responses to sensory experiences, the need for structure and routine, language, communication, and social characteristics. Woodside (2010) described case-study research as often taking the form of collecting and interpreting stories. Woodside further explained that using storytelling to report results in case-study research facilitates understanding because people relate to and "think mostly in terms of stories" (p. 44). Presenting each case as a story allowed us to capture the essence of the character.

\section{Case Studies: The Characters}

The protagonists' characteristics fell into three categories. Three cases are analytical detectives, two are determined artists, and three are lovers of language. See the Appendix for a summary of book details.

\section{The Analytical Detectives}

Christopher Boone in The Curious Incident of the Dog in the Night-Time. Our first case, Christopher, is a 15-year-old only child who lives with his dad in Swindon, England. As Christopher investigates the death of a neighbour's dog, he discovers that his father lied about his mother's death. Christopher no longer trusts his father and runs away, seeking his mother in London.

Communication. Christopher has very concrete ideas such as, "You can't trust people who lie." He has difficulty with idioms and figurative language such as "catch you later." He does not like language that he cannot visualize, such as imagining an apple in someone's eye (Haddon, 2003, p. 15). He does not like metaphors because they are lies; people do not really have a skeleton in the cupboard, and they do not truly laugh their socks off. Similes are acceptable because they are words stating one thing looks like another (i.e., "it really did look like the man had two mice hiding in his nostrils" p. 17). Christopher often finds jokes difficult to understand; he does not like words that can mean two different things. He has difficulty reading body language and explains that raising an eyebrow can mean lots of different things, which is confusing. He does not 
look at people's faces, says he cannot tell what others are thinking, and assumes that others feel the same way he does.

Sensitivities and adaptability. Christopher likes symmetry and for things to be in order; he has a keen eye for patterns. He likes the colour red and hates the colours yellow and brown. He likes to know exactly what time it is, likes prime numbers, math puzzles, and riddles. He is good with numbers and memorizing facts about countries and world capitals, astronomy, and the universe. His special interests are math, physics, and space; he hopes to be an astronaut one day. He likes Sherlock Holmes mysteries because there is a puzzle to be solved through observation and logic. He does not like novels because they are "lies about things that did not happen and they make me feel shaky and scared" (Haddon, 2003, p. 20).

Christopher is sensitive to sound, touch, crowds, and too much information, such as someone asking too many questions too fast, or too much going on in the environment. He hums and groans to block out noise, stating that when he groans he knows he is safe because he cannot hear anything else (Haddon, 2003, p. 8). He closes his eyes when too much information is coming in, such as when he is in a crowd. Christopher often hits, screams, or smashes things when he is confused. To signify a hug, his father holds up his hand with fingers splayed and they touch.

Relationships. Christopher is in the 10th grade at a segregated school for students with disabilities. Most of the students have intellectual and/or physical disabilities and work on life skills and arts and crafts. Christopher, on the other hand, is quite intelligent and will be the first person from his school to take the A-level mathematics test. He does not associate with the other students, and there is no mention of him having friends. Christopher's teacher, Siobhan, works with him on recognizing facial expressions and improving his social skills; a psychologist has taught him some calming techniques. Although the book never specifically states Christopher's disability, it is presumed he has ASD Level 1 (requiring support) without accompanying intellectual impairment and without accompanying language impairment (APA, 2013, pp. 50-59).

Ted Spark in The London Eye Mystery. Our second case also takes place in England. Ted is a 12-year-old boy who just finished his first year of secondary school, and who is described as having Asperger's syndrome. He lives in London with both parents and an older sister. His sister, Kat, is a typical teenager-very socially oriented, concerned about appearance, knows teen culture, and is adept at sneaking and lying to their parents. During the summer, Ted's cousin comes to visit for a few days and disappears. Ted investigates the mysterious disappearance with his sister, systematically making observations and tracking events to figure out where his cousin may be. Ultimately, Ted's analytic mind saves his cousin.

Communication. Ted has difficulty reading body language and facial expressions and he is a literal thinker. He has difficulty understanding idioms and why they are used. He visualizes phrases such as laughing one's head off, up your street, talking up a storm, and driving someone bananas. When someone got fired, Ted assumed the person was burned. Ted is not good at lying and has a tough time understanding when other people are lying. Like Christopher, he is very focused on accuracy and the truth. When 
interacting with others, Ted looks to the side, rather than directly at people; he also tilts his head and seems expressionless.

Sensitivities and adaptability. Ted describes himself as clumsy, and he does not like athletic activities. He does, however, like to jump on the trampoline to help him focus. He counts while he eats and, like Christopher, he groans when overwhelmed. Ted wears his school uniform even on weekends and summer break. When anxious, he flaps his hands which he describes as, "my hand shook itself out" (Dowd, 2007, p. 16). Ted is sensitive to noise, especially people talking loudly. He blinks frequently when around crowds.

Like Christopher, Ted is good at remembering facts and recites them often. Ted is especially interested in weather, which he talks about frequently to the annoyance of others. He wants to be a meteorologist. His routines include listening to the weather report during the day and to the shipping forecast at night before he goes to sleep. He is also good at mathematics and skilled at deductive reasoning.

Relationships. Like Christopher, Ted prides himself on being like Sherlock Holmes. Unlike Christopher, Ted understands how different he is from his peers. The kids do not like him because small talk is difficult for him. He tends to talk about big concepts instead. Ted says, "I know I'm a weirdo. My brain runs on a different operating system from other people's. I see things they don't and sometimes they see things I don't" (Dowd, 2007, p. 31). "And my wiring's different too ... I am very good at thinking about facts and how things work and the doctors say I am at the high-functioning end of the spectrum" (p. 37). Although Ted is good at remembering facts, he forgets everyday things like his school gym bag. Ted states, "I don't like being different. I don't like being in my brain. Sometimes it's like a big empty space where I'm all on my own. And there's nothing else, just me" (p. 39). Although Ted is very much like the character of Christopher, the reader gets more insight into Ted's inner thoughts about his lack of relationships with peers. Ted has learned if others look straight at you they could become friends; and when you are talking, if the muscles in people's faces are not doing anything, it means they are bored. Ted has no friends; he claims his mum, dad, and teacher are his only friends.

Colin Fischer in Colin Fischer. Our third case, Colin, is a 14-year-old boy when the story begins with his first day of high school. The book describes Colin as having a diagnosis of Asperger's syndrome. As in our first two cases, Colin is a detective at heart. He lives in the San Fernando Valley of California with his parents and a younger brother, Danny, who is not at all kind to Colin. He is jealous of the attention Colin gets and relishes when Colin makes mistakes. Colin's father and mother both work in the space industry. Wayne, a bully and Colin's tormentor, put Colin's head in the toilet on the first day of school. Ironically, this bully becomes his friend as Colin tries to solve the mystery of who brought a gun to school. Colin knows the bully did not bring the gun; motivated by finding the truth, he wants to clear the bully's name.

Communication. Colin avoids eye contact, often does not notice facial expressions, and when he does, he has difficulty understanding them. He has a flat, robotic tone of voice and flat affect. Like Christopher and Ted, he interprets language literally and has difficulty with figurative language and idioms. Colin is brutally honest and says what he observes, for example, telling his acquaintance that her "breasts got bigger" over the summer. Like 
Christopher, Colin does not like fiction because it is too far removed from reality; he states that inferences make him uncomfortable because he likes certainty. Like Christopher and Ted, Colin likes Sherlock Holmes and solving a mystery is part of the plot.

Sensitivities and adaptability. In describing himself to a teacher, Colin stated, "I'm diagnosed as high functioning, but I still have poor social skills and sensory integration issues that give me serious deficits in areas of physical coordination" (Miller \& Stentz, 2013, p. 39). Like the other characters, Colin does not like to be touched. His father longs for a connection with Colin. To signify a hug, his father holds up his hand with fingers splayed and says, "Coming in for a landing." Then they touch fingers like Christopher and his dad in Curious Incident. Like Ted, Colin is sensitive to fabrics and clothing, and is very sensitive to smells, which he says he can "taste." He has food preferences and will only eat crunchy foods. Like Christopher, he has colour preferences and does not like blue. Colin often suffers from sensory overload. On the first day of high school, Colin shrieks with terror at the hallway noise. Other students know Colin is sensitive to sound and use this against him by making loud noises (or ringing their cell phones) to set him off so he will bark like a dog, huddle on the floor, roll into a ball, and cover his ears with his hands.

Colin greatly dislikes disruption to his structure and routines. He has some obsessions like counting his steps and fear of germs, but is not diagnosed with obsessivecompulsive disorder. He uses bouncing, like Ted, to help him relax and think; he also finds deep pressure calming.

Relationships. Colin is included with same-age peers in general education classes. In earlier grades, Colin was given instruction in reading emotions using facial expression cards, and he keeps a chart in his notebook. In fact, the tagline of the story is "solving a mystery one facial expression at a time." He was taught appropriate conversation skills using social scripts and has memorized appropriate greetings and phrases such as "You look nice today." To prepare him for high school, his mother rented teen movies from which he created a taxonomy of high school "tribal groupings." To solve the mystery, he replicated this sociogram using pictures of classmates to group students by their social, academic, geographic, and socio-economic cliques. Colin uses his notebook to record events at school, including the movements of various groups - the nerds, popular girls, goths, and jocks. He watches his classmates "with the detached interest of an anthropologist." Colin is frequently teased and records incidents of bullying in his notebook (as in the movie Rain Man).

\section{The Determined Artists}

Taylor Simon in Wild Orchid, Waiting for No One, and The White Bicycle. Our fourth case is Taylor, an 18-year-old girl who has just finished high school. She is described by the author (Brenna, 2005, 2010, 2012) as having Asperger's syndrome. By the third book, she is 19, has completed her first year of taking classes at a university, and has been employed. Taylor lives with her mother in Saskatchewan, Canada, and is an only child. Taylor's mother gets both exasperated with and worried about her as Taylor engages in more independent activities and decision making. Taylor is very focused on

her resume, in a concrete, repetitive manner. Her main goal is employment that will lead 
to more independence, which is her broken-record focus that weaves throughout the storylines of all three books.

Communication. When young, Taylor had difficulty understanding speech. While words were confusing, numbers were comforting. Taylor focused on the sound of words rather than their meaning; and repeated words when she liked the sound. At age 18-19, she still finds that words still get stuck in her mind. She interprets language literally and often does not understand questions and expressions such as not my cup of tea or take your mind off.... She does not understand why people say things they do not mean, and why they do not say what they really mean.

Taylor is good at sorting things, is a very good artist, and reads very well. She describes herself as a follower of rules. She has a photographic memory, especially when it comes to plants and animals, and can identify them by their scientific names. She is also skilled at drawing plants and animals. If not interrupted, she engages in long monologues about gerbils and nature, which are her special interests.

Sensitivities and adaptability. Taylor is sensitive to noise, light, bright colours, and being wet. She is sensitive to smells and does not like being touched. But, she is taking ballroom dance lessons to become more accustomed to polite social touch. When people speak too fast, all she hears is vowel sounds. Feelings suddenly explode in her head until all she can see is white. But, she has learned strategies to make the white go away. Like two of our three previous cases, she is highly sensitive to certain fabrics. At age 18, she wears the same denim dress daily because it is comfortable. She does not like yellow; it makes her sneeze. She has food preferences for things that are white and has a very limited diet.

Taylor also has a diagnosis of obsessive-compulsive disorder. She obsessively counts things, including the number of words people say and the number of steps she takes. She feels comforted by doing things a certain number of times. Seven is a good number: She will pace seven times, likes sentences with seven words, and likes numbers that end with a seven. Taylor is worried about germs and obsessively cleans when stressed. She also swears when feeling anxious. As a teen, Taylor still had difficulty with eye contact and change; she preferred predictability and routine. She feared that when people left, they would not return at the end of the day.

Relationships. Taylor was diagnosed with Asperger's syndrome at age 11 (Grade 6) and was assigned a teacher's assistant who helped her with conversation skills and interpreting social situations. In high school, she received special education services. She had meltdowns that involved hitting, kicking, and biting others. Kids teased her and called her names. In the second book, she makes friends with a boy from college whose father started dating her mother. In the third book, Taylor makes friends with an elderly woman whom she saves from drowning.

Caitlin Smith in Mockingbird. Our fifth case is Caitlin, an 11-year-old girl in 5th grade who lives with her father in the U.S.A in Virginia. Her brother was her social interpreter who taught her rules for responding in a socially acceptable manner, such as "look at the person" and "deal with it." However, Caitlin's brother was a victim of a school shooting that shook up the town on what she refers to as "The Day Our Life Fell 
Apart" (Erskine, p. 5). Caitlin's mother died when she was three years old, leaving Caitlin with only her father, who is greatly incapacitated by grief.

Communication. Like Taylor, Caitlin is a good reader and an excellent artist. The sounds of some words hurt her ears, and she interprets idioms literally. Throughout the novel, Caitlin seeks "closure" believing it is a tangible thing. She finally finds closure by working with her father to complete a wooden chest her brother began before his death. Caitlin's relentless quest for closure is like Taylor's quest for employment and independence.

Sensitivities and adaptability. Caitlin is sensitive to touch. Like Taylor, she wears the same thing day after day because her skin is sensitive; she cannot wear clothes that touch her skin too much, and her father takes the tags out of her clothes. She hates recess because sound and lights make it hard for her to breathe; when someone shouts, Caitlin shakes. When she needs to tune out, she employs a strategy that she refers to as "stuffedanimaling" (Erskine, 2012, p. 28), which involves adjusting her vision so everything is out of focus, fuzzy and soft.

Caitlin has difficulty with change, difficulty with directions; she dislikes certain shades of yellow and green, and all shades of pink. She does not like colours running into each other on her clothes. When Caitlin is nervous or unsure of what to do, she flaps her hands, sucks on her sleeve, or hums. A counselor works with Caitlin on making eye contact, adapting to changes in routine, and other behaviours that will enable her to fit in better with kids her own age.

Relationships. Caitlin states that "people have a hard time understanding me because I have Asperger's" (Erskine, 2012, p. 11). She refuses to work in small groups with other children in her classroom. She spends recess with the school counselor, where they walk together watching students on the playground and talk about appropriate ways of interacting. To counterbalance skills Caitlin needs to improve, she also has a list of things she does well, including manners. Caitlin reminds others, including a bully at school, when they do not mind their manners. Caitlin's focus on manners extends to her home, where she has a sticker chart and earns rewards for displaying good manners.

Caitlin has no friends at the beginning of the book, but she makes a friend, a younger boy whose mother was also a victim of the school shooting. Although she is mainstreamed, she does not get along with children her own age. Her odd behaviours and overgeneralization of rules, such as staring at people when trying to give eye contact, cause her to be teased. By the end of the book, however, Caitlin is accepted by one of the popular girls because of her artistic ability and is invited to work on the yearbook.

\section{The Lovers of Language}

Marcelo Sandoval in Marcelo in the Real World. Our sixth case, Marcelo, is a 17year-old described as having Asperger's syndrome, who lives with his father, an attorney, and his mother, a nurse, in Boston, Massachusetts. His older sister is away attending college at Yale. Marcelo is bilingual, learning Spanish from his grandmother, and he talks about himself in the third person. The family represents a successful Hispanic family, with Marcelo experiencing advantages of his upper-middle-class upbringing such as 
attending an expensive private school for students with disabilities. Marcelo is higher in cognitive functioning than most of the students at the school, and he has a role taking care of the ponies for a therapeutic horseback riding program. Marcelo wants to continue his last year of high school at the special school, but his father wants him to leave the protective environment and attend a public school for his senior year. To prepare for the real world, Marcelo's father pushes him to work in his law firm during the summer, which results in Marcelo facing several ethical dilemmas.

Communication. In describing his Asperger's syndrome (AS), Marcelo says, "I feel dishonest when I say I have AS because the negative effects of my differences on my life are so slight compared to other kids who have AS or other forms of autism and truly suffer" (Stork, 2010, p. 55). He later adds, "I always feel like I'm doing the people who have these conditions a disservice when I use the term, because then people say, 'Oh, that doesn't seem so bad"' (Stork, p. 56). He has difficulty with facial expressions and figures of speech. He has learned some small talk, but like Ted in London Eye Mystery, prefers big talk, which is talk about important things.

Sensitivities and adaptability. Marcelo is childlike in demeanour, but tall and strong. He lifts weights daily as part of his routine. He finds comfort in schedules and makes a daily time schedule down to the minute. He likes to be organized and, like Colin, he keeps a notebook of rules, but also writes questions he has. Marcelo isolates himself when possible, has difficulty when asked to do more than one thing at a time, and cannot navigate his surroundings without a map. Marcelo does not like to be touched; and, like Ted, Caitlin, and Taylor, he wears the same clothes every day-a short sleeve white shirt, changing to long sleeves in winter. He opens and closes his fists when upset.

Relationships. The story is built around Marcelo's special interest in religion, and his focus on truth, morality, and doing the right thing. This leads him to interact with new people. A couple of these people teach him about integrity and trust, a couple teach him about selfishness and deceit. Throughout much of the novel, Marcelo is torn by trying to please others with competing interests. Marcelo's co-worker and potential love interest says that he has the heart of a poet.

Jason Blake in Anything But Typical. Our seventh case, Jason, is a 12-year-old who is a writer and a deep thinker. He lives with both parents and a younger brother in the United States, in Connecticut. The novel states that Jason was first diagnosed with ASD in the third grade. At the time of the story, Jason is in seventh grade, attends general education classes, but is not socially accepted.

Communication. Jason feels more comfortable talking with people online than in face-to-face discussions. He says he can listen better when he is not distracted by a person's face. His best subject at school is language arts because there are no right answers (which is different from Colin, Christopher, and Ted who do not like language for the same reason-no right answers). Jason's special interest is language, words, imagination, and writing stories. He started spelling at age four and learns an unfamiliar word every day, focusing on the nuances of language, stating, "Every word you choose means something you think it means, and more" (Baskin, 2009, p. 77). He gets involved with the characters of his stories and takes their perspectives. Jason states, "When I write, I can be heard. And known" (Baskin, p. 3). Yet, he misunderstands basic idioms and does 
not understand whether he has been insulted or not. Jason comes to accept his own disability through one of his characters on Storyboard (an online site where he writes and posts stories), who chooses not to undergo treatment to make him "normal" and instead chooses to stay the way he is.

Sensitivities and adaptability. At times Jason is a deep philosophical thinker, showing empathy and psychological insight; at other times, he is a very literal, concrete thinker. He has very low tolerance for change, is sensitive to noise and lights, and has a keen sense of smell. He is sensitive to touch and clothes rubbing his skin; like Caitlin, he says his "skin hurts." He rocks to comfort himself when upset, but at times experiences episodes of rage in which he hits and breaks things (like Christopher), has blackouts, and barks like a dog (like Colin). Before he gets to the point of rage, Jason flaps his hands and pulls his own hair. Regarding times when he has been destructive, he says, "Nobody could understand. When there were no words in my head, then the thoughts built up inside me and had nowhere to go" (Baskin, 2009, p. 54). Some parents wanted him out of the school because they thought he was dangerous. His occupational therapist taught him strategies like looking people in the eye, taking deep breaths, and blocking extraneous sounds and sending them away.

Relationships. Jason has no friends at school and is often teased and bullied. One boy has tried to befriend Jason, but Jason does not know how to reciprocate. Jason's social network consists of people on Storyboard. Jason meets a young girl online and starts a friendship, his first friendship. This all comes to a head when he plans to attend a Storyboard conference and finds out she will be there. He is worried she will not like him because of his ASD. He questions whether she is a girlfriend and struggles with adolescent feelings of attraction, even though he has not met her. They meet, do not become boyfriend and girlfriend, but decide to continue to read each other's work online. Taking a ride on an airplane, being away from home, and figuring out boy-girl relationships play a key role in the story. Throughout the book, Jason refers to people without autism as neurotypicals (NTs). He speaks about how NTs expect everyone to behave like they do.

Rose Howard in Rain Reign. Our eighth and final case is Rose, an 11-year-old fifth grader who lives with her father in upstate New York, in the United States. Her mother has been absent since Rose was two years old. According to the author, Rose's official diagnosis is high functioning autism (Martin, 2014). Unlike the other protagonists, Rose and her family are poor, and her father is not understanding of her disability. He loses his job, drinks excessively, and is stubborn and belligerent. Rose's school does not know what to do with her. The school sends home weekly progress reports to her dad, who gets frustrated and yells at Rose when he reads the notes. He does not understand why she cannot just control her behaviours. He interprets her behaviour as wilful disobedience. Rose's father is the only parent in the selected novels who is unsympathetic.

Communication. Rose likes words, especially homophones and homonyms, which she talks about often. She gets very excited when she finds a new homonym pair that she can add to her list. She looks at her list of homonyms to calm herself or as a reward. Like the other characters, she has difficulty with idioms. 
Sensitivities and adaptability. Rose likes rules and numbers. She frequently reminds others when they do not follow the rules. For example, she upsets the bus driver by commenting on every rule infraction made by the bus driver or other drivers on the road. When frustrated or when people do not follow the rules (like kids not putting something away or drivers not following traffic rules) she hits herself in the head and starts to cry. She also gets upset if her routine is disrupted (e.g., she eats the same thing every day). She likes things that are organized and maps that are folded neatly with the creases going in the right direction. Like Christopher, she counts prime numbers when stressed. When she is happy, she bounces. Rose is sensitive to sound; loud noises prompt her to put her hands over her ears and scream.

Relationships. Rose has a one-to-one aide at school, but no peer relationships are discussed. She is familiar with people in her small rural community but does not seem especially close to anyone other than her uncle. Her uncle takes her to and from school each day, and they cross their fingers and touch their hearts instead of hugging (like Christopher and Colin touching their fathers' palms to signify a hug). Rose does become attached to a dog she names Rain. Her relationship with Rain plays a role in her growth in perspective taking and empathy as the novel progresses.

\section{Cross-Case Analysis and Discussion}

All eight characters met the criteria for a diagnosis of ASD as defined by the Individuals with Disabilities Education Act [IDEA, 2004] and by the American Psychiatric Association's (2013) DSM-5 diagnostic criteria, which include:

- Persistent deficits in social communication and social interaction across multiple contexts such as social-emotional reciprocity; deficits in non-verbal communicative behaviours such as abnormalities in eye contact or body language; deficits in understanding and using gestures; a lack of facial expression; and difficulty adjusting behaviour to suit various social contexts.

- Restricted, repetitive patterns of behaviour, interests, or activities such as insistence on sameness, strict adherence to routines, fixated interests that are abnormal in intensity or focus, and hyper- or hypo-reactivity to sensory input.

All characters in our review would have the following specifiers (APA, 2013):

- Without accompanying intellectual impairment

- Without accompanying language impairment

- Level 1, requiring support (the least severe of the three levels of ASD).

Table 1 provides a summary comparison of the characters, including a variety of characteristics related to demographics, communication, sensory sensitivity, need for structure, and social characteristics. 
Table 1

\section{Cross-Case Descriptions}

\begin{tabular}{|c|c|c|c|c|c|c|c|c|}
\hline Book & $\begin{array}{l}\text { Curious } \\
\text { Incident }\end{array}$ & London Eye & Colin Fisher & $\begin{array}{c}\text { WO, WFNO, } \\
W B\end{array}$ & Mockingbird & Marcelo & $\begin{array}{l}\text { Anything } \\
\text { But Typical }\end{array}$ & Rain, Reign \\
\hline \multicolumn{9}{|c|}{ Demographics } \\
\hline Character & $\begin{array}{c}\text { Christopher } \\
\text { Boone }\end{array}$ & Ted Spark & Colin Fisher & $\begin{array}{l}\text { Taylor } \\
\text { Simon }\end{array}$ & $\begin{array}{l}\text { Caitlin } \\
\text { Smith }\end{array}$ & $\begin{array}{l}\text { Marcelo } \\
\text { Sandoval }\end{array}$ & $\begin{array}{l}\text { Jason } \\
\text { Blake }\end{array}$ & $\begin{array}{c}\text { Rose } \\
\text { Howard }\end{array}$ \\
\hline Location & $\begin{array}{l}\text { Swindon } \\
\text { UK }\end{array}$ & London UK & $\begin{array}{c}\text { San Fernando } \\
\text { Valley USA }\end{array}$ & $\begin{array}{c}\text { Saskatoon, } \\
\text { Canada }\end{array}$ & Virginia USA & $\begin{array}{c}\text { Boston, Mass. } \\
\text { USA }\end{array}$ & $\begin{array}{l}\text { Weston, } \\
\text { Conn. USA }\end{array}$ & $\begin{array}{c}\text { Rural } \\
\text { New York } \\
\text { USA }\end{array}$ \\
\hline $\begin{array}{l}\text { Age of } \\
\text { character } \\
\text { (yrs) }\end{array}$ & 15 & 12 & 14 & $18-19$ & 11 & 17 & 12 & $11-12$ \\
\hline Family & $\begin{array}{c}\text { Single } \\
\text { father } \\
\text { (mother left) }\end{array}$ & $\begin{array}{l}\text { Two parents, } \\
\text { one sister }\end{array}$ & $\begin{array}{l}\text { Two parents, } \\
\text { one brother } \\
\text { (mean- } \\
\text { spirited) }\end{array}$ & $\begin{array}{l}\text { Single mother } \\
\text { (sees father in } \\
\text { Wyoming on } \\
\text { occasion) }\end{array}$ & $\begin{array}{l}\text { Single father } \\
\text { (mother died), } \\
\text { one brother } \\
\text { (killed in a } \\
\text { school } \\
\text { shooting) }\end{array}$ & $\begin{array}{c}\text { Two parents, one } \\
\text { sister } \\
\text { (upper middle- } \\
\text { class Hispanic } \\
\text { family) }\end{array}$ & $\begin{array}{l}\text { Two parents, } \\
\text { one brother }\end{array}$ & $\begin{array}{l}\text { Single father } \\
\text { (alcoholic, } \\
\text { verbally } \\
\text { abusive), } \\
\text { uncle } \\
\text { (protective) }\end{array}$ \\
\hline \multicolumn{9}{|c|}{ Communication } \\
\hline Verbal & Yes & Yes & Yes & Yes & Yes & Yes & Yes & Yes \\
\hline $\begin{array}{l}\text { Difficulty with } \\
\text { lies }\end{array}$ & Yes & Yes & Yes & Yes & No & Yes & Yes & No mention \\
\hline $\begin{array}{l}\text { Difficulty with } \\
\text { idioms }\end{array}$ & Yes & Yes & Yes & Yes & Yes & Yes & Some & Yes \\
\hline $\begin{array}{l}\text { Flat affect, } \\
\text { monotone }\end{array}$ & No & No & Yes & No & No & No & No & No mention \\
\hline $\begin{array}{l}\text { Lack of eye } \\
\text { contact }\end{array}$ & Yes & Looks to the side & Yes & Yes & Yes & Yes & Yes & $\begin{array}{l}\text { Stares, over- } \\
\text { generalization }\end{array}$ \\
\hline $\begin{array}{l}\text { Difficulty } \\
\text { reading non- } \\
\text { verbal cues }\end{array}$ & Yes & Yes & $\begin{array}{l}\text { Has studied } \\
\text { intensely }\end{array}$ & Yes & Yes & No & Yes & Yes \\
\hline Echolalia & No & Some & No & Yes & No & No & No & No \\
\hline
\end{tabular}


Table 1, continued

\begin{tabular}{|c|c|c|c|c|c|c|c|c|}
\hline Book & $\begin{array}{l}\text { Curious } \\
\text { Incident }\end{array}$ & London Eye & Colin Fisher & $\begin{array}{l}\text { WO, WFNO, } \\
\text { WB * }\end{array}$ & Mockingbird & Marcelo & $\begin{array}{l}\text { Anything } \\
\text { But Typical }\end{array}$ & Rain, Reign \\
\hline \multicolumn{9}{|c|}{ Sensitivities } \\
\hline $\begin{array}{l}\text { Sensitivity to } \\
\text { touch/sound }\end{array}$ & \multicolumn{8}{|c|}{$\begin{array}{l}\text { All protagonists were highly sensitive to touch, and didn't like being touched } \\
\text { All protagonists were very sensitive to sound, with loud noises being painful }\end{array}$} \\
\hline $\begin{array}{l}\text { Clothing } \\
\text { sensitivity }\end{array}$ & No mention & Yes & Yes & Yes & Yes & Yes & Yes & No mention \\
\hline $\begin{array}{l}\text { Light and } \\
\text { motion }\end{array}$ & No & No & No & Yes & Yes & No & Yes & No mention \\
\hline Smell & Yes & No & Yes & No & No & Yes & Yes & No \\
\hline $\begin{array}{l}\text { Food } \\
\text { preferences }\end{array}$ & Yes & No & Yes & $\begin{array}{l}\text { Yes (no } \\
\text { crunchy food) }\end{array}$ & Yes & No & Yes & $\begin{array}{l}\text { Same lunch } \\
\text { everyday }\end{array}$ \\
\hline Colour likes & Red & None & No & Blue & Purple & None & None & None \\
\hline $\begin{array}{l}\text { Colour } \\
\text { dislikes }\end{array}$ & $\begin{array}{l}\text { Yellow, } \\
\text { brown }\end{array}$ & None & Blue & $\begin{array}{c}\text { Yellow (makes } \\
\text { her sneeze) }\end{array}$ & None & None & None & None \\
\hline \multicolumn{9}{|c|}{ Adaptability } \\
\hline $\begin{array}{l}\text { Need for } \\
\text { structure }\end{array}$ & \multicolumn{8}{|c|}{ All protagonists needed structure, liked order and symmetry } \\
\hline $\begin{array}{l}\text { Strict } \\
\text { adherence to } \\
\text { rules and/or } \\
\text { routines }\end{array}$ & $\begin{array}{l}\text { Needs to } \\
\text { know what } \\
\text { time it is }\end{array}$ & $\begin{array}{l}\text { Listens to } \\
\text { weather }\end{array}$ & Routines & Rules & Rules & Daily schedule & Routines & $\begin{array}{l}\text { Rules and } \\
\text { routines }\end{array}$ \\
\hline \multicolumn{9}{|c|}{ Relationships } \\
\hline Friends & No friends & No friends & Is a loyal friend & $\begin{array}{l}\text { Develops } \\
\text { friends }\end{array}$ & $\begin{array}{l}\text { Makes friend } \\
\text { with younger } \\
\text { student }\end{array}$ & $\begin{array}{l}\text { Develops a friend, } \\
\text { possible love } \\
\text { interest }\end{array}$ & $\begin{array}{l}\text { One friend } \\
\text { sticks up for } \\
\text { him }\end{array}$ & No friends \\
\hline
\end{tabular}

${ }^{*} \mathrm{WO}=$ Wild Orchid $; \mathrm{WFNO}=$ Waiting for No One; WB $=$ White Bicycle. 


\section{Family Demographics}

Four of the eight characters had single parents (Christopher, Taylor, Caitlin, and Rose), and the parents' problems played a role in the plot development of these books. These characters from single-parent homes made life difficult for their parents. The message sent was that having a child with ASD is difficult and trying at times, but ultimately manageable. The characters who lived in two-parent families appeared to be less disruptive. The message sent by these books is that families who have a member with ASD are relatively typical, with ordinary life struggles. None of the novels portrayed the family situations of the protagonists as overly saccharine, nor intolerably disruptive. This is positive because disability was not portrayed as free of difficulty, nor was it portrayed as tragic (Beckett, Ellison, Barrett, \& Shah, 2010). Tom Purser, an employee of the National Autistic Society in Britain stated, "A lot of portrayals on television have given an unhelpfully narrow look at what autism is, and its impact on the family" (Kamin, 2016). The characters in the YAL novels we reviewed depicted varying impacts on families.

All but two families were portrayed as White and middle class. One family, Rose's in Rain Reign, was portrayed as low income and as dysfunctional, with her father being a verbally abusive alcoholic. Marcelo's family was portrayed as wealthy and Hispanic. Although White children are more likely to be identified with ASD than Black or Hispanic children (White children are 1.2 times more likely to be identified than Black children and 1.5 times more likely than Hispanic children; Centers for Disease Control and Prevention, 2016); and older, more educated parents have an increased risk of having a child with autism (King \& Bearman, 2011; Liu, Zerubavel, \& Bearman, 2010), the high proportion of White, middle-class characters in our review clearly demonstrates that YAL is not accurately representing the racial, cultural, and economic diversity of children in our schools. The novels in this review were set in the United States, Canada, and England. This is probably because our selection criteria included books published in English. However, it would be interesting to determine whether adolescent novels from other parts of the world portray ASD similarly and whether family characteristics, school settings, and types of support would be different.

Four of the characters were only children (Christopher, Taylor, Rose, and Caitlin, although Caitlin did have a brother who recently died in a school shooting). The other four characters had siblings. Three of the characters had supportive siblings, and one (Colin) had a brother who actively sought opportunities to tease and torment him. While the professional literature has reported both positive and negative aspects of having a sibling with autism (Beyer, 2009), only one of the books we reviewed described the resentment a sibling may feel.

\section{Language and Communication}

All eight characters were verbal, but two characters (Colin and Justin) were described as speaking in a robot-like monotone. All but two of the characters specifically mentioned always telling the truth and having difficulty with comprehending lies and with NTs (neurotypicals) who told lies. Telling the truth was a major plot theme for the five male characters, Christopher, Ted, Colin, Jason, and Marcelo. For some characters, 
brutal honesty was a form of humor, although not humorous to the person being talked about. Caitlin commented about a man with hair sticking out of his ears and Colin commented about his friend's breasts getting bigger over the summer. The three female characters, Taylor, Caitlin, and Rose, were portrayed as strictly adhering to rules. All three characters were reprimanded when they chided others who broke the rules (students, teachers, and a bus driver).

One character, Jason, liked writing stories; and Rose was fascinated with language, especially homonyms. Christopher thought similes were interesting because they say that two things are like each other. But, Christopher thought that metaphors were lies. For example, he considered the metaphor all the world's a stage as a lie because the world is not really a stage. Interestingly, all characters were portrayed as misunderstanding idioms, which the authors used to provide light-hearted comedy. Examples of specific idioms misunderstood included: laughing one's head off, keeping close to the vest, a cup of tea, hit the hay, up your street, sticking out like a sore thumb, being let down, talking up a storm, and catch you later. The characters' difficulty with figurative language was used heavily in all the books to paint a picture of a quirky, highly intelligent individual who understood language and had a complete vocabulary, but was very literal in their interpretations. This portrayal has some support in the research literature, with findings that children with ASD Level 1 are much more likely to have difficulties with understanding idioms and tendencies toward literal interpretations than typically developing children and adults (Vogindroukas \& Zikopoulou, 2011). In isolation, children with ASD have more difficulty with idioms. However, with supportive narrative contexts and experience, the differences between children with ASD and their peers may be minimized. Whyte, Nelson, and Scharf (2014) found that when compared to typically developing peers who were matched on syntactic knowledge, children with ASD Level 1 performed similarly on idiom comprehension. This appears to confirm findings by other researchers that difficulty with figurative language is generally only experienced by individuals with ASD who have difficulty comprehending language in general (Gernsbacher \& Pripas-Kapit, 2012). The protagonists in our review did not have difficulty with language in general. Therefore, idiom misunderstanding appears to have become an unsupported stereotype creating a caricature of individuals with autism (Gernsbacher \& Pripas-Kapit). Perhaps, to create comical social situations, YAL authors have relied on stereotypes rather than creating characters that more closely reflect actual characteristics of young people with ASD. Entertainment value seems to have taken precedence over authenticity.

\section{Sensory Sensitivity}

The novels describe sensory sensitivity from a first-person perspective quite well. The characters described how sights and sounds made their heads spin, or feel full; made them feel sick, or made it hard to breathe-all symptoms of anxiety. All characters were highly sensitive to sound. "What is puzzling is that no compelling empirical evidence shows that the hearing of individuals with ASD differs physiologically from their typical peers" (Stiegler \& Davis, 2011, p. 5). All characters were sensitive to touch and/or texture. All but two characters had rigid food preferences. Four characters, (Ted, Colin, Taylor, and 
Caitlin) mentioned wearing the same clothing, or type of clothing, because of being sensitive to fabrics. Their clothing choices were also part of their insistence on sameness.

Half of the characters described being highly sensitive to smells. Three of the characters were sensitive to light and motion (Taylor, Jason, and Caitlin). Three characters had strong colour preferences, and three characters had strong dislikes for certain colours; two for the colour yellow and one for the colour blue. In a review of research studies about visual symptoms of individuals with ASD, Coulter (2009) stated that individuals with ASD often have difficulty processing and integrating visual information. Coulter listed 14 visual symptoms "highly associated with ASD" (p. 166). Symptoms occurring in our characters that appear in Coulter's list include: gaze aversion, turning head, distorted body postures or orientation, intense light sensitivity, preference for looking at objects rather than people, and consistent preference for or avoidance of a particular colour. Coulter further reported that in studies of colour perception, caretaker observations and first-hand accounts of individuals with ASD have revealed acute sensitivity to colour. In this respect, our protagonists seem to be portrayed accurately.

Characters in our review frequently had meltdowns following situations with intense visual or auditory stimulation (very loud or very bright environments). These descriptions could provide information to peers as to why youth with ASD become agitated (e.g., having meltdowns or tantrums) and/or non-responsive (e.g., withdrawing into themselves or using self-stimulatory behaviour). Armed with this information, peers may be more understanding, accepting, and supportive of their classmates with ASD. None of the characters reviewed engaged in serious self-injurious behaviour, although Rose hit her head when someone broke a rule, and a few characters talked about past incidents in which their meltdowns had involved hitting themselves. Prevalence of self-injurious behaviour in those with ASD ranges from 33\% to $71 \%$, depending on the sample and definitions applied. Richards, Oliver, Nelson, and Moss (2012) found that self-injurious behaviour was displayed by $50 \%$ of their participants with ASD, with the risk of selfinjury increasing with higher levels of impulsivity and repetitive behaviour, and with less developed social communication skills. While our protagonists' lack of self-injury is not representative of young people with ASD as a whole, it may be the case for those young people with ASD Level 1 without accompanying intellectual impairment and without accompanying language impairment (APA, 2013). In this respect, our characters' portrayals appear to be accurate.

\section{Need for Structure and Social Characteristics}

Every novel described the protagonists' adherence to routines, a need for structure and symmetry, and intense anxiety when plans, events, or circumstances changed. It appeared that many of the novel's authors created this aspect of the protagonist's personality directly from the DSM-5 diagnostic criteria (APA, 2013) or else from other novels. This is consistent with an analysis of characters with ASD in films and television series (Nordahl-Hansen, Tondevold, \& Fletcher-Watson, 2018). Nordahl-Hansen et al. found that most of the characters met nearly all of the DSM-5 criteria:

This raises the question of whether meeting all diagnostic criteria (seven portrayals scored at the maximum possible, indicating that every characteristic used in 
diagnosis was apparent in that portrayal) can be described as accurate. Instead, the characters portrayed on screen might be better described as archetypal in relation to diagnostic criteria. This could in itself lead to difficulty if people form a stereotypical view of persons with ASD. (p. 2)

The books in our review paint a picture of students with any level of ASD as needing assistance to navigate the chaotic, unpredictable world of school. Several of the characters received assistance from a one-on-one aide, either at the time of the story or in their younger years. Every character received a form of social-skills training. Five of the eight characters used a facial expressions chart, and all had received specific instruction in decoding and interpreting non-verbal communication and figures of speech. The general portrayal was of a quirky, intelligent young person who frequently makes social faux pas. There were additional commonalities among characters that could lead to further stereotypes of people with ASD having savant-like talents in areas such as mathematics and art. Three male characters (Christopher, Ted, and Colin) were highly analytical and motivated to solve mysteries like Sherlock Holmes. Two female characters (Taylor and Caitlin) were portrayed as exceptional artists. In all cases, the special skill led to the character achieving something noteworthy, and at times led to more social acceptance. For the remaining three characters who loved language (Marcelo, Jason, and Rose), their special interest neither increased nor decreased their social standing.

\section{Conclusion}

The way ASD is portrayed in YAL may influence young readers' beliefs about their peers with ASD as readers find similarities between themselves and the characters. Well written first-person descriptions may help young readers develop awareness of and empathy for what a young person with ASD experiences (Miller, 2013). This type of literature provides readers with a chance to experience vicariously what it means to live with ASD and to see a little of themselves in characters "whose lives are parallel to their own and who struggle with similar conflicts and issues" (Miller, p. 28). "Teens can meet peers with ASD in books as well as in life. Since high-functioning characters with autism are predominantly mainstreamed, they appear at school and have classmates who can get to know them" (Irwin et al., 2015, p. 14).

What general messages were sent by the books included in our review? All of the protagonists were high-functioning intellectually, bordering on gifted. This finding is similar to those of Nordahl-Hansen et al. (2018) regarding characters with ASD in film and television and to those of Irwin et al. (2015), who found that $75 \%$ of the characters with autism in 100 books were described as having splinter-savant abilities. However, until the early $2000 \mathrm{~s}$, it was estimated that $70 \%$ of those with autism had low intellectual ability (IQ < 70; see Centers for Disease Control, 2011; Dawson, Soulières, Gernsbacher, \& Mottron, 2007; Soulières, Dawson, Gernsbacher, \& Mottron, 2011). More recent prevalence studies report that a little less than half $(46 \%)$ of those with ASD have average or above average intellectual ability (IQ > 85; Dawson et al.; Soulières et al.). In our experience, we have seen characters with ASD Level 1 in movies and novels. Individuals with more severe symptoms and behaviours (such as those at Level 2 or 3, needing substantial or very substantial support) seem to appear 
more frequently in documentaries or in novels in which the protagonist has the burden of dealing with a family member with ASD. Therefore, stories told through movies and novels may not be representing the full range of strengths and weaknesses of those on the autism spectrum. Only half of individuals who experience ASD function similarly to the protagonists in the novels we reviewed. The question then becomes whether the characterizations in these novels help young readers relate to their peers with ASD better by seeing them as more similar to themselves with more capabilities than previously thought, or whether the narrow set of characterizations create and promote stereotypes about people with ASD.

Future research obtaining adolescents' impressions of these novels and their characters could guide authors, librarians, and teachers in writing and teaching these novels. Directions for future research could include interviewing adolescents who have read these books to get their impressions of the characters. Do they think the characters are believable? Are the characters similar to students they know? By reading about these characters, do the adolescent readers understand their peers with ASD a little better?

The kind of literature to which young people are exposed is likely to influence their perceptions (Beckett et al., 2010). The books we reviewed did provide positive images and may challenge ableist attitudes. The protagonists in our review had valuable skills that helped others. They were portrayed as an interesting curio: quirky geniuses who are sensitive to sounds and light, and who are thrown off by changes in routine or in the environment. The reader gets an insider's view into why sensory stimulation and changes are upsetting. Most of the characters discussed how they learned to deal with the challenges. The reader also gets an insider's view of being teased for these differences, which may promote empathy in the young people reading the books. It is our hope that by reading these novels, young adults may learn to take the perspective of a student with ASD and will advocate for students they encounter. We also hope that authors and publishers will critically examine the potential negative impacts of stereotypical portrayals of those with ASD. Finally, we hope that teachers will ask critical questions and engage in factual discussions about the portrayals of characters with ASD and other disabilities when reading these and similar novels in middle and high school classrooms.

\section{References}

References marked with an asterisk indicate works that were the subjects of our analysis.

American Library Association. (2009). Select bibliography of children's books about the disability experience. Retrieved from http://www.ala.org/awardsgrants/sites/ala.org.awardsgrants/files/ content/awardsrecords/schneideraward/2009_schneider_bio_children.pdf

American Psychiatric Association. (2013). Diagnostic and statistical manual of mental disorders (5th ed.). Washington, DC: Author.

*Baskin, N. R. (2009). Anything but typical. New York, NY: Simon and Schuster.

Beckett, A., Ellison, N., Barrett, S., \& Shah, S. (2010). “Away with the fairies?” Disability within primary-age children's literature. Disability \& Society, 25(3), 373-386.

Beyer, J. (2009). Autism spectrum disorders and sibling relationships: Research and strategies. Education and Training in Developmental Disabilities, 44(4), 444-452. 
*Brenna, B. (2005). Wild orchid. Toronto, ON, Canada: Red Deer Press.

*Brenna, B. (2010). Waiting for no one. Toronto, ON, Canada: Red Deer Press.

*Brenna, B. (2012). The white bicycle. Toronto, ON, Canada: Red Deer Press.

Centers for Disease Control and Prevention (n.d.). Autism spectrum disorder: Diagnostic criteria. Retrieved from https://www.cdc.gov/ncbddd/autism/hcp-dsm.html

Centers for Disease Control and Prevention (2011). Workshop on U.S. data to evaluate changes in the prevalence of autism spectrum disorders (ASDs): Executive summary. Atlanta, GA: Tom Harkin Global Communications Center. http://www.cdc.gov/ncbddd/autism/documents /evaluatingchanges_executivesummary.pdf

Centers for Disease Control and Prevention (2015). Autism spectrum disorder. Retrieved from http://www.cdc.gov/ncbddd/autism/research.html

Centers for Disease Control and Prevention (2016). Community report on autism from the Autism and Developmental Disabilities Monitoring (ADDM) network. Retrieved from http://www.cdc.gov/ncbddd/autism/documents/community_report_autism.pdf

Clinton, J. (2014, July 20). 'I hate writing most of the time,' says author Mark Haddon. Express. Retrieved from http://www.express.co.uk/entertainment/theatre/489747/Author-Mark-Haddonon-Curious-Incident-of-The-Dog-in-the-Night-Time

Coulter, R. A. (2009). Understanding the visual symptoms of individuals with autism spectrum disorder (ASD). Optometry \& Vision Development, 40(3), 164-175.

Dawson, M., Soulières, I., Gernsbacher, M. A., \& Mottron, L. (2007). The level and nature of autistic intelligence. Psychological Science, 18(8), 657-662.

*Dowd, S. (2007). The London Eye mystery. New York, NY: Random House, Yearling.

Dyches, T. T., Prater, M. S., \& Leininger, M. (2009). Juvenile literature and the portrayal of developmental disabilities. Education and Training in Developmental Disabilities, 44(3), 304-317.

*Erskine, K. (2012). Mockingbird. New York, NY: Philomel.

Gernsbacher, M. A., \& Pripas-Kapit, S. R. (2012). Who's missing the point? A commentary on claims that autistic persons have a specific deficit in figurative language comprehension. Metaphor \& Symbol, 27(1), 93-105. doi:10.1080/10926488.2012.656255

Gillham, B. (2010). Case study research methods. New York, NY: Bloomsbury Publishing. ProQuest Ebook Central, https://ebookcentral.proquest.com/lib/uhm/detail.action?docID=564247

*Haddon, M. (2003). The curious incident of the dog in the night-time. New York, NY: Vintage.

Individuals with Education Improvement Act. (2004). Building the legacy: IDEA 2004. Retrieved from https://sites.ed.gov/idea/

Irwin, M., Goldsmith, A. Y. \& Applegate, R. (2015). The real deal: Teen characters with autism in YA novels. Journal of Research on Libraries \& Young Adults, 6. Retrieved from http://www.yalsa.ala.org/jrlya/2015/04/the-real-deal-teen-characters-with-autism-in-ya-novels/

Jang, J., Matson, J. L., Adams, H. L., Konst, M. J., Cervantes, P. E., \& Goldin, R. L. (2014). What are the ages of persons studied in autism research: A 20-year review. Research in Autism Spectrum Disorders, 8, 1756-1760.

Kamin, D. (2016, March 30). 'The A Word' places autism front and center. New York Times. http://www.nytimes.com/2016/03/31/arts/television/the-a-word-places-autism-front-andcenter.html 
King, M. D., \& Bearman, P. S. (2011). Socioeconomic status and the increased prevalence of autism in California. American Sociological Review, 76(2), 320-346. doi:10.1177/0003122411399389

Liu, K., Zerubavel, N., \& Bearman, P. (2010). Social demographic change and autism. Demography, $47(2), 327-343$.

*Martin, A. M. (2014). Rain reign. New York, NY: Feiwel \& Friends.

Merriam, S. B. (2009). Qualitative research: A guide to design and implementation. San Francisco, CA: Jossey-Bass.

*Miller, A. E., \& Stentz, Z. (2013). Colin Fischer. New York: Razorbill.

Miller, D. L. (2013). Literature opens doors for all children. Kappan, 94(4), 28-33.

Murray, S. (2010). Autism functions/the function of autism. Disability Studies Quarterly, 30(1). Retrieved from http://dsq-sds.org/article/view/1048/1229

Nordahl-Hansen, A., Tondevold, M. \& Fletcher-Watson, S. (2018). Mental health on screen: A DSM5 dissection of portrayals of autism spectrum disorders in film and TV. Psychiatry Research, 262, 351-353. doi:10.1016/j.psychres.2017.08.050

Prater, M. A. \& Dyches, T. T. (2008). Books that portray characters with disabilities: A top 25 list for children and young adults. Teaching Exceptional Children, 40(4), 32-38.

Richards, C., Oliver, C., Nelson, L., \& Moss, J. (2012). Self-injurious behaviour in individuals with autism spectrum disorder and intellectual disability. Journal of Intellectual Disability Research, 56, 476-489. doi:10.1111/j.1365-2788.2012.01537.x

Robinson, T. (2012). Inspecting the trend of autistic-spectrum characters. Retrieved from http://www.npr.org/2012/11/18/164207965/inspecting-the-trend-of-autistic-spectrumcharacters

Rosenblum, L., \& Carroll, P. S. (2000). Characters with visual impairment in young adult literature: Are they effective role models for our teens? Re:View, 32(1), 6-22.

Silverman, D. (2004). Interpreting qualitative data: Methods for analysing talk, text, and interaction (2nd ed.). London: Sage Publications.

Soulières I., Dawson M., Gernsbacher, M. A., \& Mottron, L. (2011). The level and nature of autistic intelligence II: What about Asperger syndrome? PLoS ONE, 6(9), e25372. doi:10.1371/journal.pone.0025372

Stiegler, L., \& Davis, R. (2011). Managing sound sensitivity in individuals with ASDs. ASHA Leader, 16(1), 5-7.

*Stork, F. X. (2010). Marcelo in the real world. New York, NY: Arthur A. Levine.

Vogindroukas, I., \& Zikopoulou, O. (2011). Idiom understanding in people with Asperger syndrome/high functioning autism. Revista Da Sociedade Brasileira De Fonoaudiologia, 16(4), 390-395.

Ward, M. (2002). Voices from the margins: An annotated bibliography of fiction on disabilities and differences for young people. Westport, CT: Greenwood Press.

Whyte, E. M., Nelson, K. E., \& Scherf, K. S. (2014). Idiom, syntax, and advanced theory of mind abilities in children with autism spectrum disorders. Journal of Speech, Language \& Hearing Research, 57(1), 120-130. doi:10.1044/1092-4388(2013/12-0308)

Wikipedia. (2017). List of autistic fictional characters. Retrieved November 2017 from https://en.wikipedia.org/wiki/List_of_autistic_fictional_characters 
Woodside, A. G. (2010). Case study research: Theory, methods and practice. Bingley, UK: Emerald Group Publishing. ProQuest Ebook Central, https://ebookcentral.proquest.com/lib/uhm /detail.action?docID $=554822$

Yin, R. K. (2009). Case study research: Design and methods (4th ed.). Los Angeles, CA: Sage Publications.

\section{Authors' Note}

Correspondence concerning this article should be addressed to Professor Rhonda S. Black, 1776 University Ave., Wist Hall 127, Honolulu, HI, 96822, USA. Email: rblack@hawaii.edu 


\section{Appendix: \\ Books Included in Analysis by Year of Publication}

The Curious Incident of the Dog in the Night-Time, Mark Haddon (2003), Vintage.

Character: Christopher

Awards: Costa Book of the Year (2003), Guardian Children's Fiction Prize (2003),

Waverton Good Read Award (2004), Whitbread Award for Novel and Book of the Year (2003), McKitterick Prize (2004), Los Angeles Times Book Prize (2003), Exclusive Books Boeke Prize (2004), ALA Alex Award (2004), Commonwealth Writers' Prize for Best First Book Overall (2004)

Wild Orchid, Waiting for No One, White Bicycle, Beverley Brenna (2005, 2010, 2012), Red Deer Press.

Character: Taylor

Awards: Young Adult Book Award by the Canadian Library Association (Wild Orchid), Dolly Gray Children's Literature Award Winner (Waiting for No One), Michael L. Printz Award, Honor Book 2013 (White Bicycle)

The London Eye Mystery, Siobhan Dowd (2007), Yearling.

Character: Ted

Awards: Bisto Book of the Year: Bisto Merit Awards, Cybils Award for Middle Grade Fiction (2008), School Library Journal Best Book of the Year, Kirkus Review's Best

Children's Book Award

Anything But Typical, Nora Raleigh Baskin (2009), Simon and Schuster.

Character: Jason

Awards: ALA Notable Children's Books, ALA Schneider Family Book Award (2010), Bank Street Best Books of the Year, Junior Library Guild Selection

Marcelo in the Real World, Francisco Stork (2010), Arthur A. Levine.

Character: Marcelo

Awards: Schneider Family Book Award for Teen Book (2010), James Cook Book Award (2011), YALSA Best Book for Young Adults, Publisher's Weekly Best Book of the Year

Mockingbird, Kathryn Erskine (2012), Philomel.

Character: Caitlin

Awards: National Book Award for Young People's Literature (2010), International Reading Association Award, ALA Best Fiction for Young Adults, Dolly Gray Children's Literature Award

Colin Fischer, Ashley Miller \& Zack Stentz (2013), Razorbill.

Character: Colin

Awards: American Booksellers Association Young Adult Honor Award (2013)

Rain Reign, Ann M. Martin (2014), Feiwel \& Friends.

Character: Rose

Awards: Schneider Family Book Award for Middle School (2015), Josette Frank Award for Older Readers (2015), Charlotte Huck Honor Book (2015) 